\title{
The impact of sensory integration therapy on gross motor function in children after prenatal exposure to alcohol
}

\section{Wpływ terapii integracji sensorycznej na funkcje motoryki dużej u dzieci po prenatalnej ekspozycji na alkohol}

\author{
Jacek Wilczyński, Katarzyna Zawada \\ Department of Neurology, Neurological Rehabilitation and Kinesitherapy, Institute of Physiotherapy, Faculty of Health Sciences, \\ Jan Kochanowski University, Kielce, Poland \\ Head of the Department: Prof. JKU Jacek Wilczyński MD, PhD
}

Studia Medyczne 2015; 31 (1): 10-17

DOI: 10.5114/ms.2015.49947

Key words: physiotherapy, sensory integration, children after prenatal exposure to alcohol.

Stowa kluczowe: fizjoterapia, integracja sensoryczna, dzieci po prenatalnej ekspozycji na alkohol.

\begin{abstract}
Introduction: In Poland there are 900 cases of full-blown foetal alcohol syndrome (FAS) in neonates per year, and in 9000 children there are some symptoms of it.

Aim of the research: To analyse the impact of sensory integration (SI) therapy on gross motor skills function in children after prenatal exposure to alcohol.

Material and methods: The study was conducted on a group of 20 children aged 4-5 years with information from an interview about prenatal exposure to alcohol. The diagnosis of sensory integration disorder consisted of two 60-minute diagnostics meetings. Twelve trials with clinical observations were performed by Ayres: finger to nose, cocontraction, prone extension posture, flexed position supine, asymmetrical tonic neck reflex (ATOS), symmetrical tonic neck reflex (STOS), muscle tension, Schilder test, dynamic balance, static balance, gravitational insecurity, and trunk stabilisation. The therapeutic program included: normalisation of the vestibular and proprioceptive system, normalisation of the touch system, strengthening muscle tension, development of motion planning, development of oculomotor performance, development of motor coordination, hand therapy, integration of ATOS, STOS, development of locomotion and balance functions, and improving efficiency of gross and small motor skills.

Results and conclusions: High efficiency of SI therapy has been shown in children after prenatal exposure to alcohol on the example of gross motor skills. Positive effects of SI therapy have been shown for tests: finger to nose, in the erect position on the stomach, the flexural position on the back, ATOS, STOS, Schilder test, dynamic balance, static balance, and the uncertainty of gravity and trunk stabilisation. Only cocontraction and muscle tension tests showed no efficacy of SI therapy. The $\alpha$-Cronbach position analysis showed high reliability of the performed tests both before and after the therapy. It is advisable to continue the study on a larger sample and observation of the functional status of children after therapy.
\end{abstract}

\section{Streszczenie}

Wprowadzenie: W Polsce stwierdza się rocznie 900 przypadków pełnoobjawowego alkoholowego zespołu płodowego u noworodków, natomiast u 9 tys. dzieci występowanie niektórych jego objawów.

Cel pracy: Analiza wpływu terapii integracji sensorycznej na funkcje motoryki dużej u dzieci po prenatalnej ekspozycji na alkohol.

Materiał i metody: Badanie przeprowadzono u 20 dzieci w wieku 4-5 lat z informacja z wywiadu o prenatalnej ekspozycji na alkohol. Wykonano 12 prób z obserwacji klinicznej wg Ayres: palec do nosa, kokontrakcja, pozycja wyprostna na brzuchu, pozycja zgięciowa na plecach, asymetryczny toniczny odruch szyi (ATOS), symetryczny toniczny odruch szyi (STOS), napięcie mięśni, test Schildera, równowaga dynamiczna, równowaga statyczna, niepewność grawitacyjna, stabilizacja tułowia. Program terapeutyczny obejmował: normalizację układu przedsionkowego i proprioceptywnego, normalizację układu dotykowego, wzmacnianie napięcia mięśniowego, rozwój planowania ruchu, rozwój sprawności okoruchowej, rozwój koordynacji ruchowej, terapię ręki, integrację ATOS, STOS, rozwój lokomocji i funkcji równoważnych, podnoszenie sprawności motoryki dużej i małej. Wyniki i wnioski: Stwierdzono wysoką skuteczność terapii integracji sensorycznej u dzieci po prenatalnej ekspozycji na alkohol. Pozytywne efekty leczenia wykazano dla testów: palec do nosa, w pozycji wyprostnej na brzuchu, w pozycji zgięciowej na plecach, ATOS, STOS, Schildera. Potwierdzono również pozytywny wpływ terapii na równowagę dynamiczną, równowagę statyczną, niepewność grawitacyjną i stabilizację tułowia. Jedynie w teście na kokontrakcję i napięcie mięśni nie wykazano skuteczności terapii integracji sensorycznej. Analiza pozycji $\alpha$-Cronbacha wykazała bardzo dużą rzetelność zastosowanych testów zarówno przed terapią, jak i po niej. 


\section{Introduction}

The effect of consumption of ethyl alcohol by women during pregnancy on the foetus is a problem still poorly described and little known. In children whose mothers drank alcohol in small quantities, "occasionally", there are function problems that are difficult to diagnose and classify. In the case of minor symptoms in children with full symptomatic foetal alcohol syndrome (FAS) foetal alcohol effect is diagnosed $[1-3,7]$. In these children there is often sensory integration dysfunction.

\section{Aim of the research}

The aim of the study was to analyse the impact of sensory integration (SI) therapy on gross motor function in children after prenatal exposure to alcohol.

\section{Material and methods}

The study was conducted on a group of 20 children (14 boys, 6 girls) aged $4-5$ years with information from an interview about prenatal exposure to alcohol. Most of the children came from adoptive, foster families or children's homes. All the children were found with abnormal SI with dysfunctions typical of children with FAS spectrum, including: hyperactivity, tenacity, passivity, impulsiveness, irritability, sleep problems, anger, hypersensitivity to touch and sound, difficulty in adaptation, problems with organisation, low selfesteem, difficulty with self-control, ease of falling into depression. The diagnosis of sensory integration disorder consisted of two 60-minute diagnostics meetings. Diagnosis of SI consisted of: an interview with a parent/guardian, observation of controlled and free movements of the child in the therapeutic hall, response to sensory stimuli administered, as well as clinical observation. The main areas of evaluation and control were: gross motor skills, small motor skills, muscular tension, as well as balance responses of the body. In this work, because of the breadth of statistical analysis, only the effect of therapy on SI gross motor function is shown. Motility refers to the dexterity of movement of the whole body. Gross motility refers to movement efficiency of the whole body. Awkwardness specific symptoms are the following:

- delays in motor development in infants and toddlers and little physical activity,

- general physical awkwardness and minimal mastering in terms of strong movements associated with disturbances of muscle tone (excessive or too low tension),

- lack of coordination of movements with the collaboration of different muscle groups, giving the impression of a general awkwardness,

- delay in achieving, compared with peers, different motor skills in daily activities, and playground and sports activities,
- general slowness of movement,

- avoiding movement games,

- disruption of visual-motor coordination in games and tasks, in which the movement takes place under visual control (ball throwing, hopscotch).

Twelve trials were performed with clinical observations by Ayres: finger to nose, cocontraction, prone extension posture, flexed position supine, asymmetrical tonic neck reflex (ATOS), symmetrical tonic neck reflex (STOS), muscle tension, Schilder test, dynamic balance, static balance, gravitational insecurity, and trunk stabilisation. Each child regularly, once a week, for the period from 01.09.2011 to 28.02.2012 (6 months) participated in a 1-hour SI therapeutic session. The therapeutic program included: the normalisation of the vestibular and proprioceptive system, normalisation of the touch system, strengthening muscle tone, development of motion planning, the development of oculomotor performance, the development of motor coordination, hand therapy, integration of asymmetrical tonic neck reflex (ATOS), symmetrical tonic neck reflex (STOS), the development of locomotion and balance functions, and raising the efficiency of gross and small motor skills. Treatments were carried out in individually selected programs $[4-6,8]$. In addition, in children with tactile defence, the implementation of Wilbarger massage in home conditions was recommended. The study was conducted at the Centre for Advanced Physiotherapy Tactum Sanitas in Kielce. After 6 months of therapy 12 trials were repeated with clinical observation by Ayres. Measurement data was collected in the spreadsheet program Microsoft MS Excel and pre-treated was imported into StatSoft Statistica. Data analysis consisted of anthropometric characteristics (height, body mass, body mass index (BMI)) and tests for SI.

\section{Statistical analysis}

Basic statistical parameters were calculated, such as the arithmetic mean $(x)$, standard deviation (SD), median (Me), skewness (Sk) and kurtosis (Ku), as well as extreme values and confidence intervals for the level of $95 \%$. Variables were verified in terms of normality of distribution by Shapiro-Wilk test. An analysis of the reliability of Cronbach's $\alpha$ position was also carried out. To demonstrate the differences between the tests before and after SI therapy, Wilcoxon matched pairs test was used [17].

\section{Results}

The mean age was $4.45 \pm 0.51$ years, average body height of the subjects $1.01 \pm 0.03 \mathrm{~m}$, body weight 16.35 $\pm 1.34 \mathrm{~kg}$, mean BMI $15.73 \pm 0.52$ (Table 1 ). Gross motor test results before SI therapy showed: finger to nose $(x=2.1)$, cocontraction $(x=3)$, erect position on the stomach $(x=3.5)$, the position of flexion on the back $(x=3.55)$, ATOS $(x=2.1)$, STOS $(x=2.1)$, muscle tension $(x=2.55)$, Schilder test $(x=1.25)$, dynamic bal- 
ance $(x=0.95)$, static balance $(x=0.7)$, the uncertainty of gravity $(x=1.8)$, trunk stabilisation $(x=1.5)$, gross motor skills - overall result $(x=2.092)$ (Table 2$)$. Gross motor test results after SI therapy showed: finger to nose $(x=3)$, cocontraction $(x=3)$, erect position on the stomach $(x=4.95)$, the position of flexion on the back $(x=3.95)$, ATOS $(x=3)$, STOS $(x=3)$, muscle tension $(x=2.55)$, Schilder test $(x=2.15)$, dynamic balance $(x=2.85)$, static balance $(x=2,4)$, the uncertainty of gravity $(x=2.95)$, trunk stabilisation $(x=2)$ gross motor skills - overall result $(x=3.008)$ (Table 3$)$.

A significant result of the Shapiro-Wilk test shows that the distribution of the observed variable (gross motor) is not similar to a normal distribution (Table 4).

Cronbach's $\alpha$ value ranges from 0 to 1 . The higher the value, the greater the reliability of the scale. It is assumed that values above 0.7 indicate the correct scale reliability. The $\alpha$-Cronbach position analysis showed high reliability of the tests used both before and after therapy (Tables 5, 6). Wilcoxon matched pair test of gross motor showed significant differences in tests before and after SI therapy $(p<0.001)$ (Tables 7-9). High efficiency of SI therapy has been shown in children after prenatal exposure to alcohol on the example of gross motor skills. The positive effects of SI therapy have been shown for tests: finger to nose $(p<0.001)$, in the erect position on the stomach $(p<0.001)$, in a flexural position on the back $(p<0.05)$, ATOS $(p<0.001)$, STOS $(p<0.001)$, Schilder $(p<0.001)$, for dynamic balance $(p<0.001)$, static balance $(p<0.001)$, the uncertainty of gravity $(p<0.001)$, and trunk stabilisation $(p<0.001)$. In the cocontraction test and muscle tension there has been no efficacy of SI shown (Tables 10, 11).

\section{Discussion}

The report of the Birth Defects Monitoring Program completed by the Centres for Disease Control

Table 1. Anthropometric data of respondents

\begin{tabular}{|lcccccccc|}
\hline Variables & $N$ valid & Mean & Median & Minimum & Maximum & $\begin{array}{c}\text { Standard } \\
\text { deviation }\end{array}$ & Skewness & Kurtosis \\
Age & 20 & 4.45 & 4 & 4 & 5 & 0.510 & 0.218 & -2.183 \\
Body height & 20 & 1.018 & 1.02 & 0.94 & 1.08 & 0.036 & -0.393 & -0.228 \\
Body mass & 20 & 16.35 & 16 & 14 & 19 & 1.348 & 0.283 & -0.771 \\
Body mass index & 20 & 15.738 & 15.893 & 14.704 & 16.340 & 0.527 & -0.671 & -0.666 \\
\hline
\end{tabular}

Table 2. Gross motor skills before SI therapy

\begin{tabular}{|c|c|c|c|c|c|c|c|c|}
\hline Gross motor test & $N$ valid & Mean & Median & Minimum & Maximum & $\begin{array}{l}\text { Standard } \\
\text { deviation }\end{array}$ & Skewness & Kurtosis \\
\hline Finger to nose test & 20 & 2.1 & 2 & 2 & 3 & 0.308 & 2.888 & 7.037 \\
\hline Cocontraction test & 20 & 3 & 3 & 3 & 3 & 0.000 & & 0.000 \\
\hline $\begin{array}{l}\text { Erect position } \\
\text { on stomach test }\end{array}$ & 20 & 3.5 & 3.5 & 1 & 5 & 0.889 & -0.750 & 2.285 \\
\hline $\begin{array}{l}\text { Position of flexion } \\
\text { on back test }\end{array}$ & 20 & 3.55 & 4 & 1 & 4 & 0.759 & -2.191 & 5.892 \\
\hline Test for ATOS & 20 & 2.1 & 2 & 2 & 3 & 0.308 & 2.888 & 7.037 \\
\hline Test for STOS & 20 & 2.1 & 2 & 2 & 3 & 0.308 & 2.888 & 7.037 \\
\hline Muscle tension & 20 & 2.55 & 3 & 2 & 3 & 0.510 & -0.218 & -2.183 \\
\hline Schilder test & 20 & 1.25 & 1 & 0 & 2 & 0.550 & 0.132 & -0.076 \\
\hline $\begin{array}{l}\text { Dynamic balance } \\
\text { test }\end{array}$ & 20 & 0.95 & 1 & 0 & 1 & 0.224 & -4.472 & 20.000 \\
\hline Static balance test & 20 & 0.7 & 1 & 0 & 1 & 0.470 & -0.945 & -1.242 \\
\hline $\begin{array}{l}\text { Uncertainty } \\
\text { of gravity test }\end{array}$ & 20 & 1.8 & 2 & 1 & 3 & 0.616 & 0.120 & -0.207 \\
\hline Trunk stabilisation & 20 & 1.5 & 2 & 0 & 3 & 0.889 & -0.250 & -0.497 \\
\hline $\begin{array}{l}\text { Gross motor - } \\
\text { overall result }\end{array}$ & 20 & 2.092 & 2.167 & 1.167 & 2.833 & 0.388 & -0.109 & 0.985 \\
\hline
\end{tabular}


Table 3. Gross motor skills after SI therapy

\begin{tabular}{|c|c|c|c|c|c|c|c|c|c|}
\hline $\begin{array}{l}\text { Gross motor } \\
\text { test }\end{array}$ & $N$ valid & Mean & Median & Minimum & Maximum & $\begin{array}{l}\text { Standard } \\
\text { deviation }\end{array}$ & Skewness & Kurtosis & Difference \\
\hline $\begin{array}{l}\text { Finger to nose } \\
\text { test }\end{array}$ & 20 & 3 & 3 & 3 & 3 & 0.000 & 0.000 & 0.000 & 0.900 \\
\hline $\begin{array}{l}\text { Cocontraction } \\
\text { test }\end{array}$ & 20 & 3 & 3 & 3 & 3 & 0.000 & 0.000 & 0.000 & 0.000 \\
\hline $\begin{array}{l}\text { Erect position } \\
\text { on stomach } \\
\text { test }\end{array}$ & 20 & 4.95 & 5 & 4 & 5 & 0.224 & -4.472 & 20.000 & 1.450 \\
\hline $\begin{array}{l}\text { Position } \\
\text { of flexion } \\
\text { on back test }\end{array}$ & 20 & 3.95 & 4 & 3 & 4 & 0.224 & -4.472 & 20.000 & 0.400 \\
\hline Test for ATOS & 20 & 3 & 3 & 3 & 3 & 0.000 & 0.000 & 0.000 & 0.900 \\
\hline Test for STOS & 20 & 3 & 3 & 3 & 3 & 0.000 & 0.000 & 0.000 & 0.900 \\
\hline Muscle tension & 20 & 2.55 & 3 & 2 & 3 & 0.510 & -0.218 & -2.183 & 0.000 \\
\hline Schilder test & 20 & 2.15 & 2 & 2 & 3 & 0.366 & 2.123 & 2.776 & 0.900 \\
\hline $\begin{array}{l}\text { Dynamic } \\
\text { balance test }\end{array}$ & 20 & 2.85 & 3 & 2 & 3 & 0.366 & -2.123 & 2.776 & 1.900 \\
\hline $\begin{array}{l}\text { Static balance } \\
\text { test }\end{array}$ & 20 & 2.4 & 3 & 1 & 3 & 0.940 & -0.945 & -1.242 & 1.700 \\
\hline $\begin{array}{l}\text { Uncertainty } \\
\text { of gravity test }\end{array}$ & 20 & 2.95 & 3 & 2 & 3 & 0.224 & -4.472 & 20.000 & 1.150 \\
\hline $\begin{array}{l}\text { Trunk } \\
\text { stabilisation }\end{array}$ & 20 & 2.3 & 2 & 1 & 3 & 0.733 & -0.553 & -0.834 & 0.800 \\
\hline $\begin{array}{l}\text { Gross motor - } \\
\text { overall result }\end{array}$ & 20 & 3.008 & 3.083 & 2.500 & 3.250 & 0.213 & -1.115 & 0.571 & 0.920 \\
\hline
\end{tabular}

(CDC), based on data from 1500 hospitals, suggests that the prevalence of reported FAS cases in the U.S. population is $0.3-0.9$ per 10,000 births [9]. On the other hand, Abel and Sokolow, after reviewing 19 epidemiological works from around the world, evaluated the prevalence of FAS at 1.9 per 1000 live births [9]. According to the CDC report, incidence rates of FAS in 10,000 births vary depending on the ethnicity of mothers [9]. The world incidence of FAS is estimated at 3-9 per 1000 live births [9]. In Poland there are 900 cases of full-blown FAS in neonates per year, and in 9000 children there are some symptoms of it [15, 16]. The study conducted at the Institute of Mother and Child in Warsaw, under the guidance of Prof. Krzysztof Niemiec, involving the tests of urine samples of pregnant women, who reported abstinence, for the presence of indicators of alcohol decay ( $\beta$-hexosaminidase and $\gamma$-glutamyl) showed that one third of women drank alcohol while knowing about their pregnancy [7]. A survey made in the Sopot Laboratory of Social Research in 2005 on behalf of PARPA, on a representative group of 1038 women in reproductive age (18-40 years), showed that one third of the women drank alcohol during pregnancy [7]. Most
Table 4. Shapiro-Wilk test of normality of distribution of gross motor skills

\begin{tabular}{|c|c|c|c|c|c|}
\hline \multicolumn{3}{|c|}{ Before therapy } & \multicolumn{3}{|c|}{ After therapy } \\
\hline$N$ & $w$ & $p$ & $N$ & $w$ & $p$ \\
\hline 20 & 0.947 & 0.31865 & 20 & 0.878 & 0.016 \\
\hline
\end{tabular}

common among the women who admitted to drinking during pregnancy were those with secondary education, and the least common were women with primary education. Most of the women who drank were from small and medium-sized cities, and the least from large cities and the countryside. The IBSOS laboratory, on behalf of the foundation "Rodzić po ludzku", in 2005 conducted a survey on a representative sample of 1000 Poles aged 15 and above. One third of the women (33.5\%) who gave birth to one or more children admitted consuming small amounts of alcohol during pregnancy. Although $83 \%$ of the respondents had heard that even the smallest amount of alcohol could be dangerous, one third (31.7\%) said that a small amount of alcohol could have a positive 
Table 5 . Analysis of reliability of $\alpha$-Cronbach position before SI therapy

\begin{tabular}{|lccccc|}
\hline Gross motor test & $\begin{array}{c}\text { Mean } \\
\text { - when } \\
\text { removed }\end{array}$ & $\begin{array}{c}\text { Value when } \\
\text { removed }\end{array}$ & $\begin{array}{c}\text { Standard } \\
\text { deviation } \\
\text { when } \\
\text { removed }\end{array}$ & $\begin{array}{c}\text { Total } \\
\text { position } \\
\text { correlation }\end{array}$ & $\begin{array}{c}\alpha \text { when } \\
\text { removed }\end{array}$ \\
Finger to nose test & 6.555 & 1.579 & 1.256 & 0.605 & 0.899 \\
Cocontraction test & 6.255 & 1.741 & 1.319 & -0.175 & 0.912 \\
Erect position on stomach test & 6.555 & 1.331 & 1.154 & 0.949 & 0.878 \\
Position of flexion on back test & 6.367 & 1.387 & 1.178 & 0.732 & 0.891 \\
Test for ATOS & 6.905 & 1.657 & 1.287 & 0.629 & 0.904 \\
Test for STOS & 6.555 & 1.579 & 1.256 & 0.605 & 0.899 \\
Muscle tension & 6.405 & 1.439 & 1.200 & 0.689 & 0.893 \\
Schilder test & 6.838 & 1.408 & 1.186 & 0.710 & 0.892 \\
\hline Dynamic balance test & 6.938 & 1.641 & 1.281 & 0.505 & 0.904 \\
Static balance test & 7.021 & 1.484 & 1.218 & 0.628 & 0.896 \\
Uncertainty of gravity test & 6.655 & 1.317 & 1.148 & 0.835 & 0.884 \\
Trunk stabilisation & 6.755 & 1.141 & 1.068 & 0.836 & 0.893 \\
\hline
\end{tabular}

Table 6. Analysis of reliability of $\alpha$-Cronbach position after SI therapy

\begin{tabular}{|lccccc|}
\hline Gross motor test & $\begin{array}{c}\text { Mean }- \text { when } \\
\text { removed }\end{array}$ & $\begin{array}{c}\text { Value when } \\
\text { removed }\end{array}$ & $\begin{array}{c}\text { Standard deviation } \\
\text { when removed }\end{array}$ & $\begin{array}{c}\text { Total position } \\
\text { correlation }\end{array}$ & $\begin{array}{c}\alpha \text { when } \\
\text { removed }\end{array}$ \\
Finger to nose test & 9.545 & 0.646 & 0.804 & -0.156 & 0.732 \\
Cocontraction test & 9.545 & 0.646 & 0.804 & 0.238 & 0.732 \\
$\begin{array}{l}\text { Erect position } \\
\text { on stomach test }\end{array}$ & 9.555 & 0.611 & 0.782 & 0.481 & 0.715 \\
$\begin{array}{l}\text { Position of flexion } \\
\text { on back test }\end{array}$ & 9.557 & 0.603 & 0.777 & 0.470 & 0.712 \\
Test for ATOS & 10.045 & 0.646 & 0.804 & 0.146 & 0.732 \\
Test for STOS & 9.545 & 0.646 & 0.804 & 0.196 & 0.732 \\
Muscle tension & 9.695 & 0.467 & 0.684 & 0.666 & 0.656 \\
Schilder test & 9.828 & 0.587 & 0.766 & 0.247 & 0.722 \\
Dynamic balance test & 9.595 & 0.507 & 0.712 & 0.734 & 0.662 \\
Static balance test & 9.745 & 0.314 & 0.560 & 0.698 & 0.670 \\
\hline $\begin{array}{l}\text { Uncertainty } \\
\text { of gravity test }\end{array}$ & 9.561 & 0.594 & 0.771 & 0.415 & 0.710 \\
Trunk stabilisation & 9.778 & 0.408 & 0.638 & 0.598 & 0.670 \\
\hline
\end{tabular}

effect for the mother and child. Expertise drawn up on the basis of a nationwide survey in 2009 showed that $29 \%$ of women consuming alcohol in the last year were pregnant [7]. The effect of ethyl alcohol on the foetus is a problem that is still poorly described and little known. In children whose mothers drank alcohol there are functional difficulties that are difficult to diagnose and classify, and often sensory integration dysfunction. For these children SI therapy is neces- sary and effective [10-16, 18-33]. This work, because of the breadth of statistical analysis, only shows the effects of SI therapy on gross motor function. This motility refers to the dexterity of movement of the whole body. Therapies were carried out via individually selected programs $[4-6,8]$. In addition, in children with tactile defence, the implementation of Wilbarger massage in home conditions was recommended. Similar results of the therapy were obtained in studies of 
Table 7. The standardised results of gross motor tests before SI therapy

\begin{tabular}{|lcccccc|}
\hline Motor gross tests & N valid & Mean & Median & Minimum & Maximum & Standard deviation \\
Finger to nose test & 20 & 0.700 & 0.667 & 0.667 & 1.000 & 0.103 \\
Cocontraction test & 20 & 1.000 & 1.000 & 1.000 & 1.000 & 0.000 \\
Erect position on stomach test & 20 & 0.700 & 0.700 & 0.200 & 1.000 & 0.178 \\
Position of flexion on back test & 20 & 0.888 & 1.000 & 0.250 & 1.000 & 0.190 \\
Test for ATOS & 20 & 0.350 & 0.333 & 0.333 & 0.500 & 0.051 \\
Test for STOS & 20 & 0.700 & 0.667 & 0.667 & 1.000 & 0.103 \\
Muscle tension & 20 & 0.850 & 1.000 & 0.667 & 1.000 & 0.170 \\
Schilder test & 20 & 0.417 & 0.333 & 0.000 & 0.667 & 0.183 \\
Dynamic balance test & 20 & 0.317 & 0.333 & 0.000 & 0.333 & 0.075 \\
Static balance test & 20 & 0.233 & 0.333 & 0.000 & 0.333 & 0.157 \\
Uncertainty of gravity test & 20 & 0.600 & 0.667 & 0.333 & 1.000 & 0.205 \\
Trunk stabilisation & 20 & 0.500 & 0.667 & 0.000 & 1.000 & 0.296 \\
Gross motor - overall result & 20 & 0.605 & 0.628 & 0.343 & 0.819 & 0.113 \\
\hline
\end{tabular}

Table 8. The standardised results of gross motor tests after SI therapy

\begin{tabular}{|lccccccc|}
\hline Motor gross tests & $N$ valid & Mean & Median & Minimum & Maximum & $\begin{array}{c}\text { Standard } \\
\text { deviation }\end{array}$ & $\begin{array}{c}\text { Difference } \\
\text { K-P }\end{array}$ \\
Finger to nose test & 20 & 1.000 & 1.000 & 1.000 & 1.000 & 0.000 & 0.300 \\
Cocontraction test & 20 & 1.000 & 1.000 & 1.000 & 1.000 & 0.000 & 0.000 \\
Erect position on stomach test & 20 & 0.990 & 1.000 & 0.800 & 1.000 & 0.045 & 0.290 \\
Position of flexion on back test & 20 & 0.988 & 1.000 & 0.750 & 1.000 & 0.056 & 0.100 \\
Test for ATOS & 20 & 0.500 & 0.500 & 0.500 & 0.500 & 0.000 & 0.150 \\
Test for STOS & 20 & 1.000 & 1.000 & 1.000 & 1.000 & 0.000 & 0.300 \\
Muscle tension & 20 & 0.850 & 1.000 & 0.667 & 1.000 & 0.170 & 0.000 \\
Schilder test & 20 & 0.717 & 0.667 & 0.667 & 1.000 & 0.122 & 0.300 \\
Dynamic balance test & 20 & 0.950 & 1.000 & 0.667 & 1.000 & 0.122 & 0.633 \\
Static balance test & 20 & 0.800 & 1.000 & 0.333 & 1.000 & 0.313 & 0.567 \\
Uncertainty of gravity test & 20 & 0.983 & 1.000 & 0.667 & 1.000 & 0.075 & 0.383 \\
Trunk stabilisation & 20 & 0.767 & 0.667 & 0.333 & 1.000 & 0.244 & 0.267 \\
Gross motor - overall result & 20 & 0.879 & 0.903 & 0.726 & 0.958 & 0.069 & 0.274 \\
\hline
\end{tabular}

a population of children with developmental disabilities from Kielce town. These were studies carried out on a group of 153 children admitted for treatment in their third year of life. The aim of this study was to analyse the impact of integrating the senses (mostly proprioception and the vestibular system) on vocabulary development. The results of the diagnosis of sensory integration processes show that the most affected areas are associated with static and dynamic balance and after-rotation nystagmus. They also indicate significant disorders of the development of the vestibular system. Early diagnosis of sensory integra-
Table 9. Wilcoxon matched pair test of gross motor

\begin{tabular}{|lcccc|}
\hline $\begin{array}{l}\text { Gross motor } \\
\text { before and after } \\
\text { the therapy }\end{array}$ & $N$ valid & $T$ & $Z$ & $P$-value \\
\hline
\end{tabular}

tion disorders in the population will significantly prevent more serious problems in the development of children. Disorders of sensory integration processes impede the normal development of speech and language. The largest deficits in the area of vocabulary 
Table 10. Wilcoxon matched pair test of gross motor

\begin{tabular}{|c|c|c|c|c|c|c|}
\hline \multirow[t]{2}{*}{ Motor gross tests } & \multicolumn{2}{|c|}{ Initial test } & \multicolumn{2}{|c|}{ Final test } & \multirow{2}{*}{$\begin{array}{c}\text { Difference } \\
\text { K-P }\end{array}$} & \multirow{2}{*}{$\frac{\text { Wilcoxon test }}{N \text { valid }}$} \\
\hline & $N$ valid & Mean & $N$ valid & Mean & & \\
\hline Finger to nose test & 20 & 2.1 & 20 & 3 & 0.9 & $<0.001$ \\
\hline Cocontraction test & 20 & 3 & 20 & 3 & 0 & - \\
\hline Erect position on stomach test & 20 & 3.5 & 20 & 4.95 & 1.45 & $<0.001$ \\
\hline Position of flexion on back test & 20 & 3.55 & 20 & 3.95 & 0.4 & $<0.05$ \\
\hline Test for ATOS & 20 & 2.1 & 20 & 3 & 0.9 & $<0.001$ \\
\hline Test for STOS & 20 & 2.1 & 20 & 3 & 0.9 & $<0.001$ \\
\hline Muscle tension & 20 & 2.55 & 20 & 2.55 & 0 & - \\
\hline Schilder test & 20 & 1.25 & 20 & 2.15 & 0.9 & $<0.001$ \\
\hline Dynamic balance test & 20 & 0.95 & 20 & 2.85 & 1.9 & $<0.001$ \\
\hline Static balance test & 20 & 0.7 & 20 & 2.4 & 1.7 & $<0.001$ \\
\hline Uncertainty of gravity test & 20 & 1.8 & 20 & 2.95 & 1.15 & $<0.001$ \\
\hline Trunk stabilisation & 20 & 1.5 & 20 & 2.3 & 0.8 & $<0.001$ \\
\hline
\end{tabular}

Table 11. Wilcoxon matched pair test of gross motor for standardised values

\begin{tabular}{|lccccccc|}
\hline Motor gross tests & \multicolumn{2}{c}{ Initial test } & \multicolumn{2}{c}{ Final test } & Difference & Wilcoxon test \\
\cline { 2 - 3 } & $N$ valid & Mean & $N$ valid & Mean & & Value of $p$ \\
Finger to nose test & 20 & 0.700 & 20 & 1.000 & 0.9 & $<0.001$ \\
Cocontraction test & 20 & 1.000 & 20 & 1.000 & 0 & - \\
Erect position on stomach test & 20 & 0.700 & 20 & 0.990 & 1.45 & $<0.001$ \\
Position of flexion on back test & 20 & 0.888 & 20 & 0.988 & 0.4 & $<0.05$ \\
Test for ATOS & 20 & 0.350 & 20 & 0.500 & 0.9 & $<0.001$ \\
Test for STOS & 20 & 0.700 & 20 & 1.000 & 0.9 & $<0.001$ \\
Muscle tension & 20 & 0.850 & 20 & 0.850 & 0 & - \\
Schilder test & 20 & 0.417 & 20 & 0.717 & 0.9 & $<0.001$ \\
Dynamic balance test & 20 & 0.317 & 20 & 0.950 & 1.9 & $<0.001$ \\
Static balance test & 20 & 0.233 & 20 & 0.800 & 1.7 & $<0.001$ \\
Uncertainty of gravity test & 20 & 0.600 & 20 & 0.983 & 1.15 & $<0.001$ \\
Trunk stabilisation & 20 & 0.500 & 20 & 0.767 & 0.8 & $<0.001$ \\
\hline
\end{tabular}

development were reported in the area of creating sub words and defining concepts in connection with disturbances in dynamic and static balance. There was also a correlation between vestibular system disorders and acquiring vocabulary skills [34-36].

\section{Conclusions}

A high efficiency of SI therapy has been shown in children after prenatal exposure to alcohol in the example of gross motor skills. Positive effects of SI therapy have been shown for trials: finger to nose, in the erect position on the stomach, in the flexural po- sition on the back, ATOS, STOS, Schilder, for dynamic balance, static balance, the uncertainty of gravity, and trunk stabilisation. Only in the cocontraction and muscle tension tests was no efficacy of SI shown. The analysis of the reliability of $\alpha$-Cronbach position showed high reliability of the tests before and after therapy. It is advisable to continue the study on a larger sample as well as observation of the functional status of children after therapy.

\section{Conflict of interest}

The authors declare no conflict of interest. 


\section{References}

1. Abel EL. Was the fetal alcohol syndrome recognized by the Greeks and Romans? Alcohol Alcohol 1999; 34: 868-72.

2. Archibald SL, Fennema-Notestine C, Gamst A, et al. Brain dysmorphology in individuals with severe prenatal alcohol exposure. Dev Med Child Neurol 2001; 43: 148-54.

3. Astley SJ, Clarren SK. Measuring the facial phenotype of individuals with prenatal alcohol exposure: correlations with brain dysfunction. Alcohol Alcohol 2001; 36: 147-59.

4. Ayres AJ. Sensory integration and learning disorders. Western Psychological Services, Los Angeles 1991.

5. Ayres AJ. Sensory integration and the child. Western Psychological Services, Los Angeles 2005.

6. Ayres AJ. Types of sensory integrative dysfunction among disabled learners. Am J Occup Ther 1972; 26: 13-8.

7. Banach M. Alkoholowy zespół płodu. Teoria, diagnostyka, praktyka. WAM, Kraków 2011.

8. Bundy AC, Lane SJ, Murray EA. Sensory integration: theory and practice. 2nd ed. Davis Philadelphia PA 2002.

9. Burden MJ, Jacobson SW, Sokolow R, et al. Effects of prenatal alcohol exposure on attention and working memory at 7.5 years of age. Alcohol Clin Exp Res 2005; 29: 443-52.

10. Burd L, Peterson L, Kobrinsky N. Fetal alcohol spectrum disorders and childhood cancer: a concise review of case reports and future research considerations. Pediatr Blood Cancer 2013; 30: 24886.

11. Fröschl B, Brunner-Ziegler S, Wirl C. Prevention of fetal alcohol syndrome. GMS Health Technol Assess 2013; 9: 10.

12. Dinis-Oliveira RJ, Magalhães T, Moreira R, et al. Clinical and forensic signs related to ethanol abuse: a mechanistic approach. Toxicol Mech Methods 2014; 24: 81-110.

13. Karunamuni G, Gu S, Doughman YQ, et al. Ethanol exposure alters early cardiac function in the looping heart: a mechanism for congenital heart defects? Am J Physiol Heart Circ Physiol 2014; 306: H414-21.

14. Kaur S, Jain S, Sodhi HB, et al. Optic nerve hypoplasia. Oman J Ophthalmol 2013; 2: 77-82.

15. Klecka M. Organiczne uszkodzenia mózgu u dzieci wywołane prenatalnym działaniem alkoholu. Objawy i wczesne rozpoznanie alkoholowego zespołu płodowego FAS. Bliżej Przedszkola 2004; 4: 31.

16. Klecka M, Janas-Kozik M, Krupka-Matuszczyk I. Rozwój diagnostyki poalkoholowego spektrum zaburzeń rozwojowych - przegląd narzędzi diagnostycznych. Psychiatria i Psychologia Kliniczna 2010; 4: 298-302.

17. Komputerowy program statystyczny: Statistica.7.1 Statsoft, 2012.

18. Landgraf MN, Nothacker M, Kopp IB, Heinen F. The diagnosis of fetal alcohol syndrome. Dtsch Arztebl Int 2013; 110: 703-10

19. Landgraf MN, Nothacker M, Kopp IB, Heinen F. The diagnosis of fetal alcohol syndrome. Dtsch Arztebl Int 2013; 110: 703-10.

20. Lange S, Shield K, Rehm J, Popova S. Prevalence of fetal alcohol spectrum disorders in child care settings: a metaanalysis. Pediatrics 2013; 132: 980-95.

21. Lee N. Sensory integration difficulties. J Human Lact 2001; 17: 210.

22. Maas V. Uczenie się przez zmysły. Wprowadzenie do teorii integracji sensorycznej. Wydawnictwo Szkolne i Pedagogiczne, Warsaw 1998; 14-46.
23. May PA, Gossage JP. Estimating the prevalence of fetal alcohol syndrome. A summary. Alcohol Res Health 2001; 25: 159-67.

24. May PA, Gossage JP, Kalberg WO, et al. Prevalence and epidemiologic characteristics of FASD from various research methods with an emphasis on recent in school studies. Dev Disabil Res Rev 2009; 15: 176-92.

25. Memo L, Gnoato E, Caminiti S, et al. Fetal alcohol spectrum disorders and fetal alcohol syndrome: the state of the art and new diagnostic tools. Early Hum Dev 2013; 89 Suppl 1: S40-3.

26. Midro AT. Istnieć, żyć i być kochanym. Możliwości wspomagania rozwoju dzieci z zespołami uwarunkowanymi genetycznie. Impuls, Kraków 2011.

27. Poitra BA, Marion S, Dionne M, et al. A school based screening program for fetal alcohol syndrome. Neurotoxicol Teratol 2003; 25: 725-9.

28. Riley EP, McGee CL. Fetal alcohol spectrum disorders: an overview with emphasis on changes in brain and behavior. Department of Psychology and the Center for Behavioral Teratology, San Diego State University, California 2005.

29. Ruparelia A, Pearn ML, Mobley WC. Aging and intellectual disability: insights from mouse models of down syndrome. Dev Disabil Res Rev 2013; 18: 43-50.

30. Szumiło T. Neuropsychologiczny profil dziecka z FASD. Studium przypadku. Wydawnictwo Edukacyjne PARPAMEDIA, Warsaw 2008.

31. Wozniak JR, Fuglestad AJ, Eckerle JK, et al. Choline supplementation in children with fetal alcohol spectrum disorders has high feasibility and tolerability. Nutr Res 2013; 33: 897-904.

32. Vargas S, Camilli G. A meta-analysis of research on sensory integration treatment. Am J Occup Ther 1999; 53: 189-98.

33. Yordanova J, Banaschewski T, Kolev V. Abnormal early stages of task stimulus processing in children with attention-deficit hyperactivity disorder-evidence from eventrelated gamma oscillations. Clin Neurophysiol 2001; 112: 1096-108.

34. Chalik P. Wyniki badania logopedycznego. Biuletyn Pedagogiczny, Kielce 2013; 3: 38-54.

35. Horecka-Lewitowicz A, Lewitowicz P, Adamczyk-Gruszka $\mathrm{O}$, et al. Symptoms, medical course and procedures in foetal alcohol syndrome. Studia Medyczne 2013; 29: 195-8.

36. Horecka-Lewitowicz A, Lewitowicz P, Adamczyk-Gruszka $\mathrm{O}$, et al. Fetal alcohol syndrome - causes, diagnostic criteria and prevalence. Studia Medyczne 2014; 30: 48-50.

\section{Address for correspondence:}

Prof. Jacek Wilczyński MD, PhD

Department of Neurology, Neurological Rehabilitation and Kinesitherapy

Institute of Physiotherapy

Faculty of Health Sciences

Jan Kochanowski University

ul. Żeromskiego 5, 25-369 Kielce, Poland

Phone: +48 603703926

E-mail: jwilczynski@onet.pl 